\title{
Enhancement of Photocatalytic and Antibacterial Activities of ZnO:Ag Nanopowders Through the Addition of Bamboo Charcoal: An Efficient Natural Adsorbent
}

\author{
K. Nithiyadevi ${ }^{1,2} \cdot$ K. Ravichandran ${ }^{1}$
}

Received: 14 March 2017/Revised: 7 April 2017/Published online: 4 July 2017

(c) The Chinese Society for Metals and Springer-Verlag GmbH Germany 2017

\begin{abstract}
This research article explains the removal of methylene blue (MB) and malachite green (MG) from aqueous solution using adsorption/photodegradation activity of $\mathrm{ZnO}: \mathrm{Ag} /$ bamboo charcoal (BC) nanocomposite. In addition, the antibacterial studies of the prepared samples were tested against Staphylococcus aureus (S. aureus) Gram-positive and Escherichia coli (E. coli) Gram-negative bacteria by the well diffusion method. The $\mathrm{ZnO}: \mathrm{Ag} / \mathrm{BC}$ nanocomposite exhibits superior photocatalytic activity compared with $\mathrm{ZnO}: \mathrm{Ag}$. Remarkable degradation efficiencies of $93.95 \%(\mathrm{MB})$ and $95.75 \%$ (MG) were recorded for $\mathrm{ZnO}: \mathrm{Ag} / \mathrm{BC}$ nanocomposite after $45 \mathrm{~min}$. The degradation process follows a pseudo-first-order kinetics. The rate constant of $\mathrm{ZnO}: \mathrm{Ag} / \mathrm{BC}$ nanocomposite is two times greater than that of pristine $\mathrm{ZnO}$ nanopowder for the degradation of $\mathrm{MB}$ dye, while for $\mathrm{MG}$ dye degradation, it is three times. It is found that the $\mathrm{ZnO}: \mathrm{Ag} / \mathrm{BC}$ nanocomposite shows a higher rate of dye removal due to excellent adsorbing properties of bamboo charcoal (BC). The $\mathrm{ZnO}: \mathrm{Ag} / \mathrm{BC}$ nanocomposite showed better antibacterial properties compared to $\mathrm{ZnO}: \mathrm{Ag}$. In this study, the samples were prepared using a simple and low-cost soft chemical route and they were characterized by optical, structural, surface morphological, antibacterial and photocatalytic properties. These characterization studies substantiate the discussions on the photocatalytic and antibacterial activities of the synthesized samples.
\end{abstract}

KEY WORDS: Bamboo charcoal; Adsorbent; ZnO; Photocatalysis; Antibacterial

\section{Introduction}

In current trends, a lot of semiconductors such as, $\mathrm{TiO}_{2}$, $\mathrm{ZnO}, \mathrm{ZrO}_{2}, \mathrm{CdS}, \mathrm{SnO}_{2}$ and $\mathrm{WO}_{3}$ have been studied for photocatalysis [1-6] and these are all have band gap energy in the UV (ultraviolet) region. Hence, these catalysts support photocatalytic reactions under the illumination of UV

Available online at http://link.springer.com/journal/40195

K. Ravichandran

kkr1365@yahoo.com

$1 \quad$ PG Research and Department of Physics, AVVM Sri Pushpam College (Autonomous), Poondi, Thanjavur, Tamil Nadu 613 503, India

2 Department of Physics, Bharathidasan University Constituent College (Women), Orathanadu, Tamil Nadu 614 625, India radiation. To absorb visible light radiation, band gap energy must be reduced or divided into different sub-band gaps using doping transition metal ions or noble metals, incorporating carbon materials or graphene and its derivative materials $[7,8]$. $\mathrm{ZnO}$ is an n-type semiconducting material, which has wide band gap, nontoxic, abundant in nature and an eco-friendly photocatalyst [9]. It absorbs wide range of spectrum, which also makes it more appropriate for solar cells, photocatalysis and photovoltaic applications. However, $\mathrm{ZnO}$ has some negative aspects in photocatalysis, such as less utilization of visible light and fast retardation of photo-generated electron-hole pairs. It is essential to extend the optical absorption of $\mathrm{ZnO}$ from the range of UV to visible light region and retarding the recombination of electron-hole pairs for improving the photocatalytic efficiency of $\mathrm{ZnO}$. Doping of noble metals, such as $\mathrm{Ag}, \mathrm{Au}$ and $\mathrm{Pt}$, has possible method to overcome 
the drawbacks of $\mathrm{ZnO}$ photocatalyst [10, 11]. Among these noble metals, $\mathrm{Ag}$ is the most excellent element as dopant for $\mathrm{ZnO}$ since it is inexpensive.

Nowadays the removal of dye molecules from wastewaters is an important environmental issue. There are several approaches for the treatment of wastewater, such as sedimentation, electrochemical methodology, advanced oxidation processes (AOPs), biological treatment, ion exchange and adsorption [12-14]. Adsorption has been proven to be an effectual process for dye removal due to its low cost and environmental friendliness [15]. Therefore, a new bioresource of bamboo charcoal (BC), which is a costeffective adsorbent, attracts more attention compared with other adsorption materials [16]. BC is produced from moso bamboo, which is an ethnic group of evergreen plants grown in tropical regions. Moreover, bamboo is considered to be a rapid renewable and sustainable biomass material in several fields. In addition, BC has a number of beneficial characteristics, which includes high electric conductivity, self-lubricity and high absorption capacity.

In the present work, we explore the $\mathrm{ZnO}: \mathrm{Ag} / \mathrm{BC}$ nanocomposite material for significant improvement in adsorption as well as photodegradation of methylene blue (MB) and malachite green (MG) under visible light irradiation in aqueous solution. $\mathrm{ZnO}$ nanoparticles have been synthesized using various methods, like sol-gel, sonochemical, combustion, hydrothermal, co-precipitation, solid-state reaction and soft chemical methods [17, 18]. Among these, the soft chemical method is selected for the present work because of its low hazardousness, simplicity, low processing temperatures and low cost, which are appropriate for the preparation of nanostructured materials on a large scale. Hence, this soft chemical route is used to synthesize $\mathrm{ZnO}: \mathrm{Ag}$ and $\mathrm{ZnO}: \mathrm{Ag} / \mathrm{BC}$ nanocomposite.

\section{Materials and Methods}

\subsection{Preparation of Bamboo Charcoal}

Pieces of bamboo with age ranging from 5 to 6 years old were collected from the region of Tamil Nadu, India. To remove the dust and other contaminants on the surface of the bamboo culm, initially tap water was used several times to remove the contaminants and then thoroughly cleaned with deionized water and then dried at room temperature for 1 day. The well-cleaned bamboo culm was chopped in the size ranging from $1 \mathrm{~cm} \times 0.5 \mathrm{~cm}$. The cleaned and dried bamboo pieces were taken in quartz crucible and kept in a muffle furnace at $500{ }^{\circ} \mathrm{C}$ for $3 \mathrm{~h}$. The obtained charcoal of bamboo was grained well with the help of china dish. Then required amount of bamboo charcoal was taken to synthesize the composite.

\subsection{Synthesis Process}

The $\mathrm{ZnO}: \mathrm{Ag}$ and $\mathrm{ZnO}: \mathrm{Ag} / \mathrm{BC}$ nanocomposites were synthesized using a soft chemical method. Zinc acetate dihydrate $\left(\mathrm{Zn}\left(\mathrm{CH}_{3} \mathrm{COO}\right)_{2} 2 \mathrm{H}_{2} \mathrm{O}\right)(0.2 \mathrm{M})$ (assay $\geq 98 \%$ ) was used as the host precursor, and bamboo charcoal (5 wt $\%$ ) and silver nitrate (4 at.\%) were used as the dopant precursor. Zinc acetate dihydrate $(8.77 \mathrm{~g})$ and the dopant precursors were dissolved in $200 \mathrm{~mL}$ of deionized water, and $\mathrm{NaOH}$ solution was added drop by drop with the starting solution to maintain the $\mathrm{pH}$ value at 5 . The solution was stirred for $3 \mathrm{~h}$ at a temperature of $80{ }^{\circ} \mathrm{C}$ and then cooled to room temperature. After $3 \mathrm{~h}$, the settled precipitate was separated by filtration and it was washed with a mixture of ethanol and water in the ratio of 1:3. Finally, it was calcined for $2 \mathrm{~h}$ at a temperature of $400{ }^{\circ} \mathrm{C}$ in a muffle furnace to get the final product.

\subsection{Characterization Techniques}

The crystalline structure of the powders was studied by X-ray diffraction method (XRD, PANalytical-PW 340/60 X'pert PRO) with $\mathrm{Cu} K_{\alpha}(1.5406 \AA)$ radiation. The optical absorbance measurements were taken using a PerkinElmer UV-vis-NIR double beam spectrophotometer (LAMBDA35). The photoluminescence spectra were obtained using spectrofluorometer (Jobin-Yvon-FLUROLOG-FL3-11) with xenon lamp $(450 \mathrm{~W})$ as the excitation source of wavelength of $325 \mathrm{~nm}$ at room temperature. Fourier transforms infrared (FTIR) spectra were recorded using PerkinElmer RX-I FTIR spectrophotometer. The surface morphology was observed using a scanning electron microscope (SEM, HITACHI S- 3000H).

\subsection{Evaluation of Photocatalytic Activity}

The photocatalytic activity of the samples was studied by the degradation of methylene blue (MB) and malachite green (MG) under visible light irradiation. In the photoreactor, the water is circulating in a jacket surrounding the reactor and the temperature is maintained constant. $50 \mathrm{~mL}$ of aqueous solution of $\mathrm{MB} / \mathrm{MG}$ was taken in a beaker, and $50 \mathrm{mg}$ of the synthesized sample was added and stirred well. The absorption spectrum was recorded for the initial solution. After reaching the adsorption equilibrium (30 $\mathrm{min}$ ), the reaction was beginning by irradiating the system with $500 \mathrm{~W}$ tungsten lamp (light source). At equal intervals of time (15 min), $5 \mathrm{~mL}$ of the samples was collected, centrifuged and then filtered to remove the catalyst if any present in the sample. The optical absorption was recorded each time using a UV-vis spectrophotometer. The photodegradation of both the dyes was evaluated by measuring the optical absorbance of the sample. 


\subsection{Evaluation of Antibacterial Activity}

The antibacterial activities of the prepared $\mathrm{ZnO}: \mathrm{Ag}$ nanopowder and $\mathrm{ZnO}: \mathrm{Ag} / \mathrm{BC}$ nanocomposite were evaluated using agar well diffusion method. MHA agar plates were inoculated with bacterial strain. A well of diameter was made with a sterile cork borer, and it was filled with $200 \mu \mathrm{g} / \mathrm{mL}$ of the test sample and incubated under suitable conditions for $24 \mathrm{~h}$. After the incubation period, the zone of inhibition was measured in $\mathrm{mm}$.

\section{Results and Discussion}

\subsection{Structural Studies}

Figure 1 shows the $\mathrm{XRD}$ patterns of $\mathrm{ZnO}: \mathrm{Ag}$ and $\mathrm{ZnO}: \mathrm{Ag} /$ BC nanocomposite. The XRD peaks emerged at Bragg angles $2 \theta$ of $31.82^{\circ}, 34.35^{\circ}, 36.23^{\circ}, 47.48^{\circ}, 56.53^{\circ}, 62.80^{\circ}$, $67.89^{\circ}, 69.05^{\circ}$ and $72.68^{\circ}$ are found to be associated with the (hkl) planes (100), (002), (101), (102), (110), (103), (112), (201) and (004), respectively. All of the abovementioned diffraction peaks are exactly matched well with standard XRD pattern of $\mathrm{ZnO}$ powder as given in the JCPDS file (card no. 36-1451). The sharp and intense diffraction peaks of the samples show that the prepared samples are of good crystalline nature. It is obvious from the XRD profiles that the synthesized powder is crystallized with hexagonal wurtzite structure of $\mathrm{ZnO}$. No secondary phases related to silver are observed indicating complete incorporation of silver into the $\mathrm{ZnO}$ lattice. $\mathrm{ZnO}: \mathrm{Ag} / \mathrm{BC}$ nanocomposite shows weak diffraction peaks near $2 \theta$ of $24^{\circ}$ and $28^{\circ}$ due to the reflection of carbon. This clearly indicates that $\mathrm{BC}$ is a typical amorphous phase of

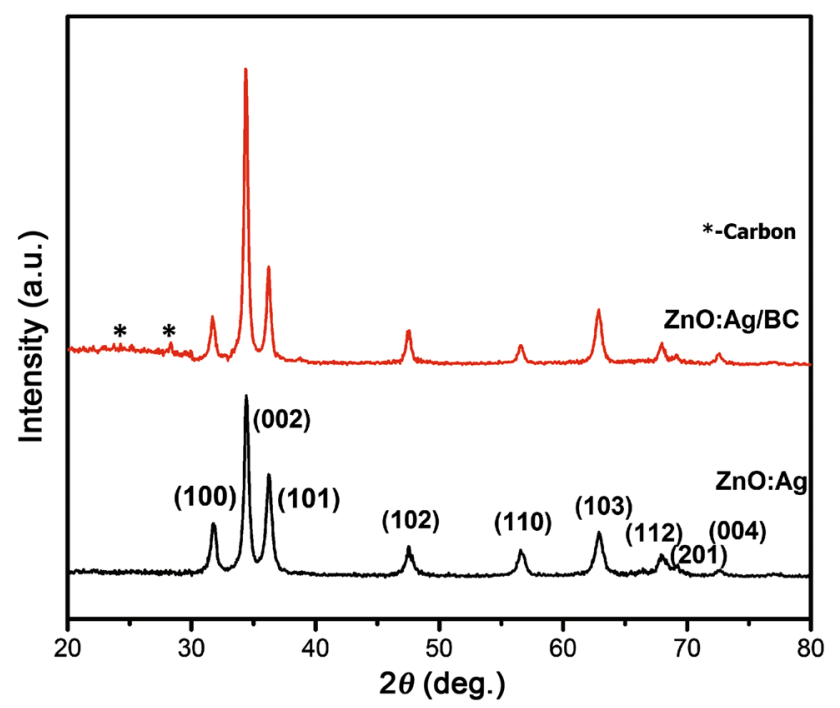

Fig. $1 \mathrm{XRD}$ patterns of $\mathrm{ZnO}: \mathrm{Ag}$ and $\mathrm{ZnO}: \mathrm{Ag} / \mathrm{BC}$ nanopowders carbon. The crystallite size $(D)$ of the $\mathrm{ZnO}: \mathrm{Ag}$ and $\mathrm{ZnO}: \mathrm{Ag} / \mathrm{BC}$ powders is calculated using the Scherrer's formula [19]

$D=\frac{0.9 \lambda}{\beta \cos \theta}$,

where $\lambda(0.15406 \mathrm{~nm})$ is the wavelength of $\mathrm{Cu} K_{\alpha}$ radiation, $\theta$ is the Bragg's angle and $\beta$ is the full-width at halfmaximum.

The lattice constants $a$ and $c$ are estimated using the following relations [20],

$\frac{1}{d_{h k l}^{2}}=\frac{4}{3 a^{2}}\left(h^{2}+h k+k^{2}\right)+\frac{l^{2}}{c^{2}}$,

where $d$ is the inter-planar distance and $(h k l)$ are Miller indices.

The determined structural parameters are given in Table 1 . The computed lattice constants $a$ and $c$ are very close to that of the standard values of powder $\mathrm{ZnO}$ (JCPDS no. 36-1451), indicating that the structure is not affected by $\mathrm{Ag}$ and $\mathrm{BC}$ addition.

\subsection{Surface Morphological and Compositional Studies}

The morphologies of $\mathrm{BC}, \mathrm{ZnO}: \mathrm{Ag}$ and $\mathrm{ZnO}: \mathrm{Ag} / \mathrm{BC}$ photocatalysts were characterized via SEM images (Fig. 2). From Fig. 2, it can be seen that $\mathrm{ZnO}: \mathrm{Ag}$ particles were uniformly dispersed over the bamboo charcoals, and the particle size is in the range of nanometer scale, which is beneficial to photocatalytic activities due to quantum confinement effect. If the particle size becomes less than a certain critical limit, it gives rise to quantum confinement of the electronic movement. This leads to a change in valence and conduction bands of the materials, which gives rise to change in discrete energy level that means either the electric potential of valence band changes more positive or the conduction band electric potential changes more negative. Therefore, the oxidation or reduction of nanosized $\mathrm{ZnO}: \mathrm{Ag} / \mathrm{BC}$ photocatalyst activities is enhanced. Moreover, no obvious agglomerations of $\mathrm{ZnO}: \mathrm{Ag} / \mathrm{BC}$ particles are found. The particle size values for $\mathrm{ZnO}: \mathrm{Ag}$ and $\mathrm{ZnO}: \mathrm{Ag} / \mathrm{BC}$ are in the range of 59 and $52 \mathrm{~nm}$, respectively. These results specify that the particle size decreases with the addition of charcoal, which is in good agreement with

Table 1 Structural parameters of the synthesized samples

\begin{tabular}{lllll}
\hline Sample & $D(\mathrm{~nm})$ & \multicolumn{2}{l}{ Lattice constants } & \multirow{2}{*}{$c / a$} \\
\cline { 3 - 4 } & & $a(\AA)$ & $c(\AA)$ & \\
\hline $\mathrm{ZnO}: \mathrm{Ag}$ & 25.25 & 3.2342 & 5.2121 & 1.6115 \\
$\mathrm{ZnO}: \mathrm{Ag} / \mathrm{BC}$ & 24.14 & 3.2523 & 5.2078 & 1.6012 \\
\hline
\end{tabular}



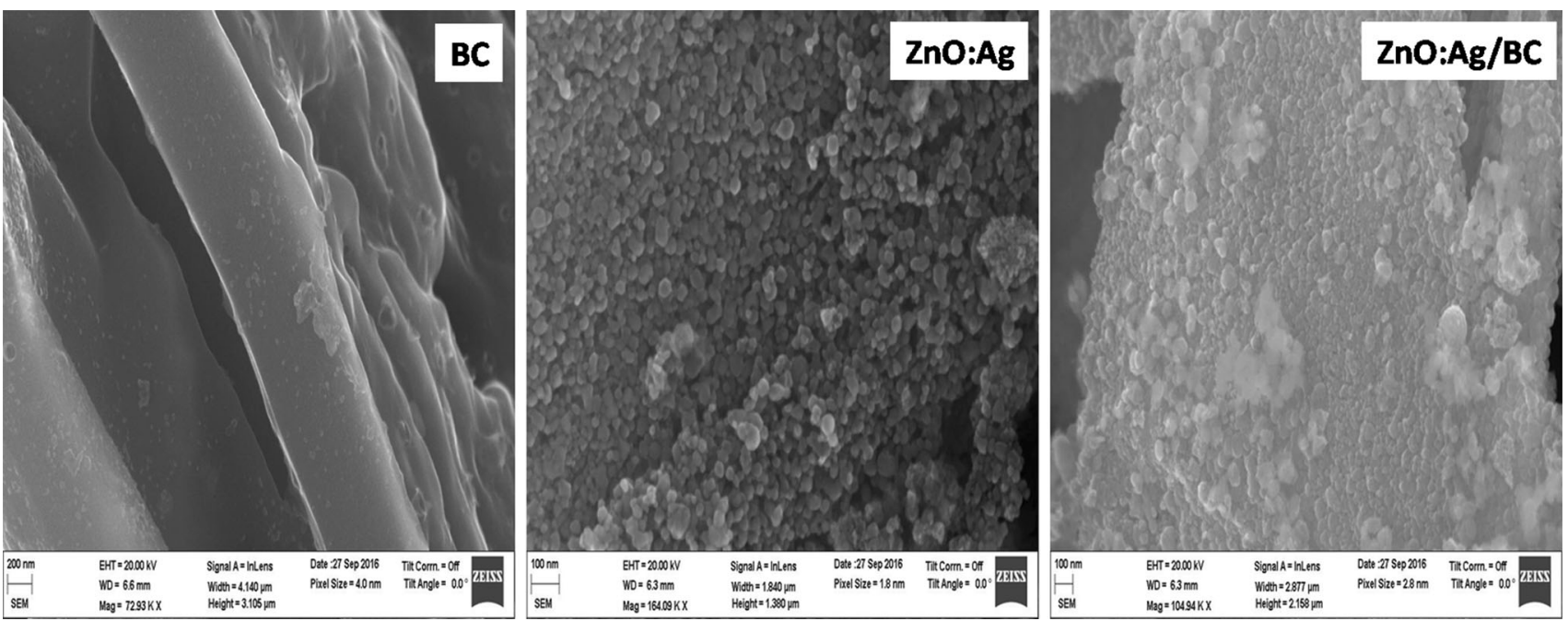

Fig. 2 SEM images of $\mathrm{ZnO}: \mathrm{Ag}$ and $\mathrm{ZnO}: \mathrm{Ag} / \mathrm{BC}$ nanopowders

the crystallite sizes estimated from the XRD results. The EDS analysis of the samples confirmed the presence of zinc, oxygen, silver and carbon in the samples as shown in Fig. 3.

\subsection{PL Studies}

Photoluminescence (PL) spectroscopy can be used as an effective tool to evaluate surface defects of the synthesized samples. The PL spectra of $\mathrm{ZnO}: \mathrm{Ag}$ and $\mathrm{ZnO}: \mathrm{Ag} / \mathrm{BC}$ nanocomposites are shown in Fig. 4. The spectra depict that a UV emission peak at $390 \mathrm{~nm}$ corresponds to the near-band edge emission of $\mathrm{ZnO}$ [21]. The peak at $416 \mathrm{~nm}$ is related to the $\mathrm{Zn}$ interstitial [22]. The peak at $440 \mathrm{~nm}$ is associated with singly ionized oxygen vacancies [23]. These oxygen vacancies play a vital role in the generation of hydroxyl radicals. These hydroxyl radicals enhance the photocatalytic efficiency of the synthesized samples as

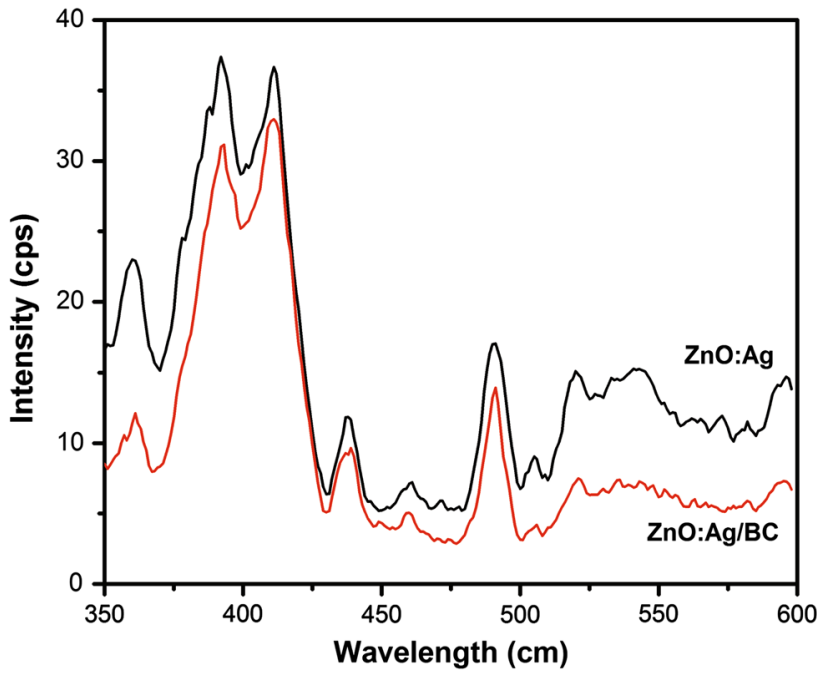

Fig. 4 Photoluminescence spectra of $\mathrm{ZnO}: \mathrm{Ag}$ and $\mathrm{ZnO}: \mathrm{Ag} / \mathrm{BC}$ nanopowders

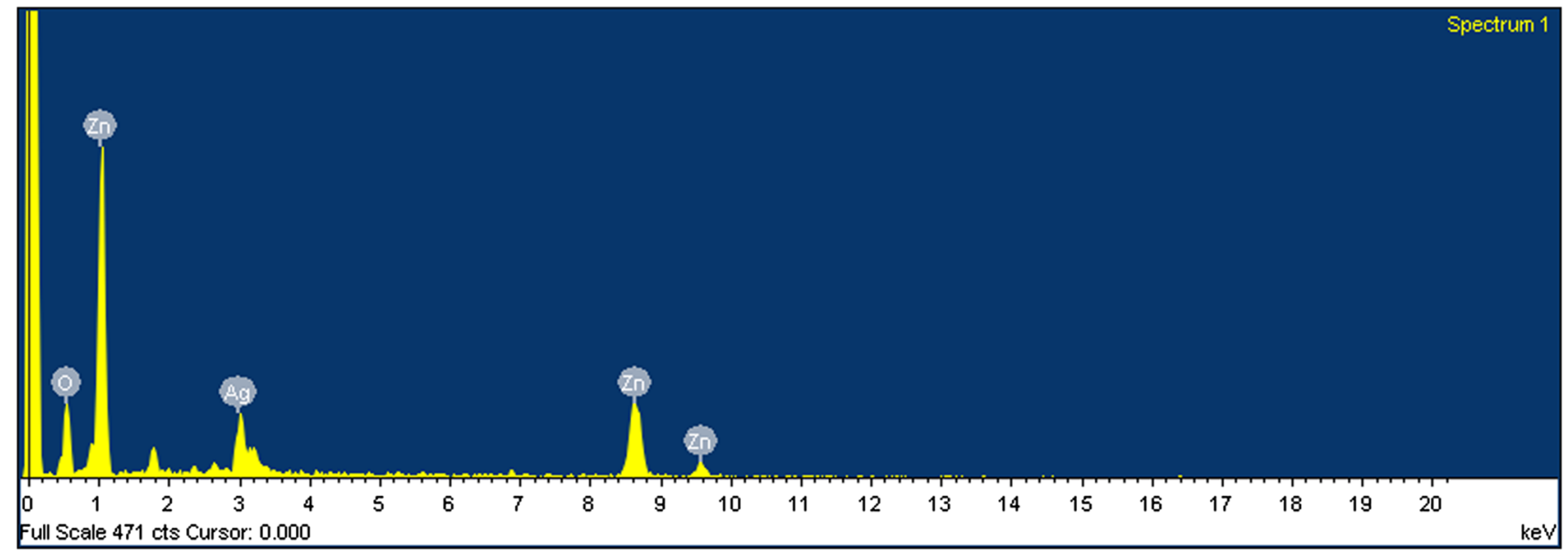

Fig. 3 EDX result of $\mathrm{ZnO} \mathrm{Ag} / \mathrm{BC}$ nanopowder 
discussed in the forth coming section. Further, the overall $\mathrm{PL}$ intensity of $\mathrm{ZnO}: \mathrm{Ag} / \mathrm{BC}$ nanocomposite is significantly lower compared with $\mathrm{ZnO}$ :Ag. The lower intensity of the emission peak shows that the lower recombination rate of electron-hole pairs increases the lifetime of charge carriers and thereby enhances the photocatalytic activities.

\subsection{FTIR Studies}

FTIR spectra of $\mathrm{ZnO}: \mathrm{Ag}$ and $\mathrm{ZnO}: \mathrm{Ag} / \mathrm{BC}$ nanocomposite recorded in the range of $400-4000 \mathrm{~cm}^{-1}$ are shown in Fig. 5. The characteristics absorption band at $\sim 3446 \mathrm{~cm}^{-1}$ can be attributed to stretching of surface hydroxyl groups [24]. The peak appears in the range of $2340 \mathrm{~cm}^{-1}$ is assigned to $\mathrm{C}-\mathrm{H}$ stretching, whereas the peak at $\sim 1722 \mathrm{~cm}^{-1}$ corresponds to stretching vibration of $\mathrm{H}_{2} \mathrm{O}$ $[25,26]$. The peak at $1580 \mathrm{~cm}^{-1}$ represents $\mathrm{C}=\mathrm{C}$ vibrations in aromatic systems [27]. The peak occurring at $950 \mathrm{~cm}^{-1}$ can be assigned to $\mathrm{C}-\mathrm{O}$ stretching [28]. The peak at $\sim 440 \mathrm{~cm}^{-1}$ can be characterized to the stretching vibrations of $\mathrm{Zn}-\mathrm{O}$ [29].

\subsection{Photocatalytic Activity}

The absorption spectra of MB and MG solution for different time intervals are illustrated in Fig. 6. As seen from the spectra, the intensity of absorption peaks decreases with the increase in the irradiation time and nearly a complete degradation of dye molecules was achieved in $45 \mathrm{~min}$. The decreased intensity shows that the dye molecules are decomposed due to catalyst and light energy. The mechanism of photodegradation of $\mathrm{ZnO}$ has been already discussed in detail in our previous work [30]. When the $\mathrm{ZnO}: \mathrm{Ag} / \mathrm{BC}$ photocatalyst irradiated with photons of

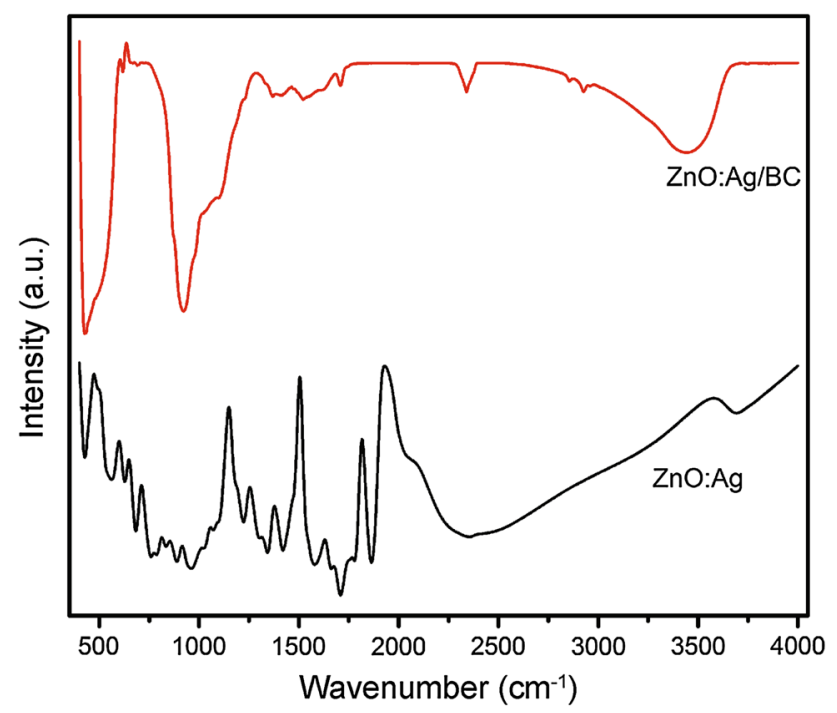

Fig. 5 FTIR spectra of $\mathrm{ZnO}: \mathrm{Ag}$ and $\mathrm{ZnO}: \mathrm{Ag} / \mathrm{BC}$ nanopowders energy equal to or greater than its band gap energy, valence band electrons are excited to the conduction band producing electron-hole pairs. The holes react with surface $\mathrm{OH}^{-}$groups and $\mathrm{H}_{2} \mathrm{O}$ molecules to produce hydroxyl radicals $(\mathrm{OH}$.), which are strong oxidizing species and can degrade the MB and MG dyes. The electrons in the conduction band can reduce oxygen $\left(\mathrm{O}_{2}\right)$ to generate superoxide anions $\left(\mathrm{O}_{2}\right.$. $)$. Consequently, $\mathrm{O}_{2}$. reacts with hydrogen ions $\left(\mathrm{H}^{+}\right)$to produce hydrogen peroxide $\left(\mathrm{H}_{2} \mathrm{O}_{2}\right)$ and $\mathrm{OH}$. These reactive oxygen species $\left(\mathrm{OH}\right.$., $\mathrm{O}_{2}$. and $\left.\mathrm{H}_{2} \mathrm{O}_{2}\right)$ are responsible for degrading the organic dye solutions into $\mathrm{H}_{2} \mathrm{O}$ and $\mathrm{CO}_{2}$. The percentage of degradation was determined using the following relation [31], and the results are presented in Table 2:

Degradation efficiency $\%(\eta)=\left(C_{0}-C_{t}\right) / C_{0} \times 100$,

where $C_{0}$ is the initial dye concentration and $C_{t}$ is the dye concentration after irradiation time $t$. The photodegradation efficiency of $\mathrm{ZnO}: \mathrm{Ag} / \mathrm{BC}$ is found to be higher than that of $\mathrm{ZnO}: \mathrm{Ag}$. The results clearly show that the photocatalytic activity of $\mathrm{ZnO}: \mathrm{Ag}$ is improved when it is combined with BC.

The steady-state photocatalytic rate is expressed in Langmuir-Hinshelwood model with first-order reaction kinetics. The plots between $\left(C / C_{0}\right)$ and irradiation time, drawn for all the samples, are shown in Fig. 7, which clearly depicts that $\mathrm{ZnO}: \mathrm{Ag} / \mathrm{BC}$ nanopowder has high adsorption in dark condition. The photocatalytic kinetics of photocatalysis can be evaluated by the following relation [32]:

$\ln \left(C_{0} / C\right)=k_{\text {app }} \times t$,

where $k$ is the constant of the pseudo-first-order rate. A plot of $\ln \left(C_{0} / C\right)$ vs irradiation time for the MB and MG photodegradation by the synthesized samples is shown in Fig. 8. Linear relations between $\ln \left(C_{0} / C\right)$ and the time of irradiation for both the synthesized samples indicate that the photodegradation process obeys pseudo-first-order kinetics. The values of the pseudo-first-order rate constant $k$ could be obtained from the linear fit curves. The estimated values of $k$ for $\mathrm{ZnO}: \mathrm{Ag}$ and $\mathrm{ZnO}: \mathrm{Ag} / \mathrm{BC}$ nanostructured samples are listed in Table 2. From Table 2, it is seen that $\mathrm{ZnO}: \mathrm{Ag} / \mathrm{BC}$ nanocomposite showed high rate constant compared to $\mathrm{ZnO}: \mathrm{Ag}$ nanopowder.

The BC materials have the following features. (1) BC has an excellent adsorption capacity, and hence it effectively adsorbs organic compounds from waste water. (2) The surface hydrophilic functional group of the carbon nanomaterials (BC) acts as a suitable substrate for the uniform growth of $\mathrm{ZnO}: \mathrm{Ag}$ with hierarchical morphology. (3) It suppresses the agglomeration of $\mathrm{ZnO}$ nanoparticles when they grow on the BC. (4) It acts as excellent conductive pathway toward collecting and transporting the 

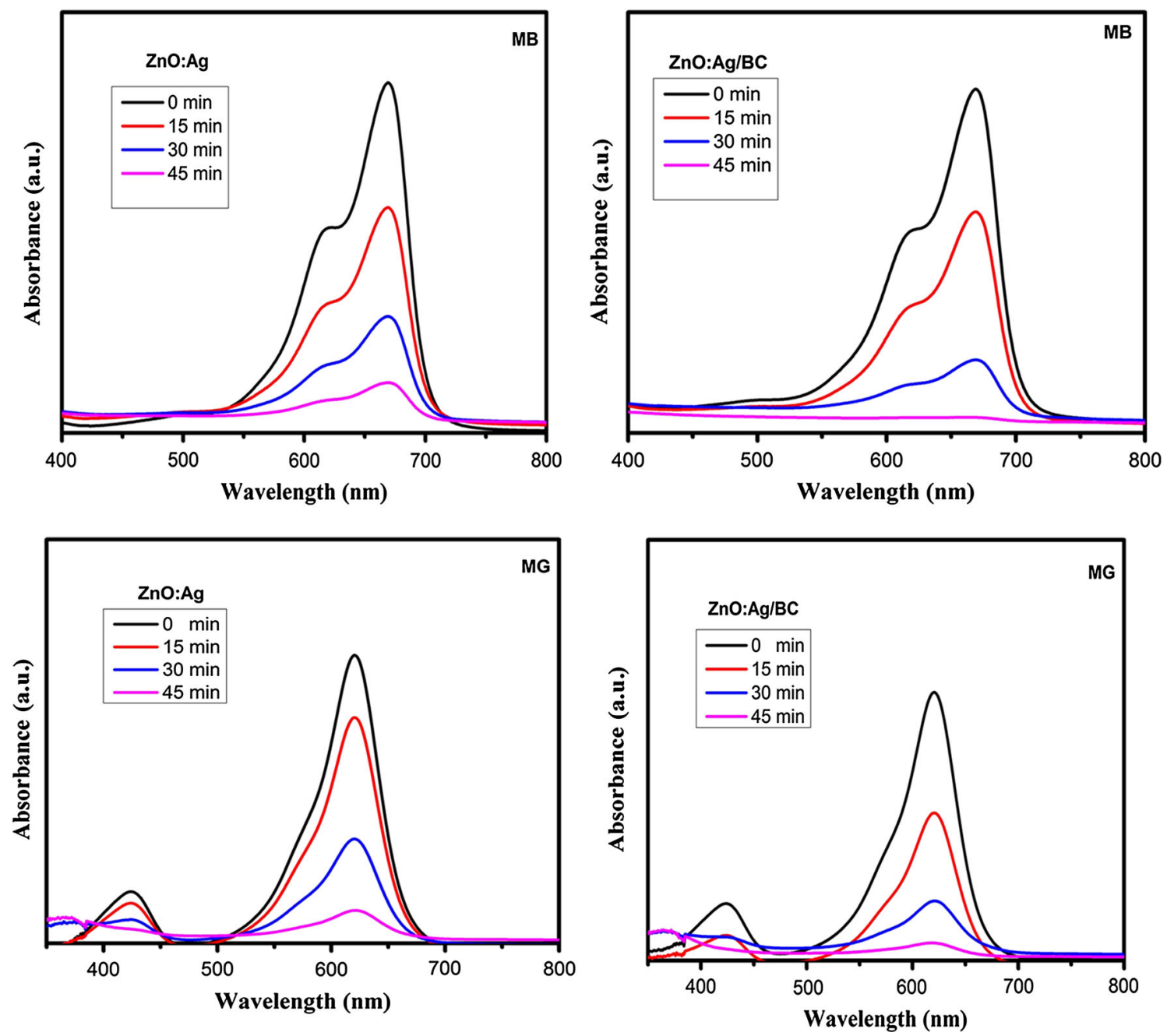

Fig. 6 Absorption spectra of aqueous solutions of dye solution in $\mathrm{ZnO}: \mathrm{Ag}$ and $\mathrm{ZnO}: \mathrm{Ag} / \mathrm{BC}$ nanopowders

Table 2 Photocatalytic degradation efficiencies and rate constant values of the synthesized samples against $\mathrm{MB}$ and $\mathrm{MG}$

\begin{tabular}{llllll}
\hline Catalyst & \multicolumn{2}{l}{ Degradation efficiency $(\%)$} & & \multicolumn{2}{l}{ Rate constant } \\
\cline { 2 - 3 } & MB & MG & & MB & MG \\
\hline ZnO:Ag & 86.24 & 88.81 & & 0.0484 & 0.0379 \\
ZnO:Ag/BC & 93.95 & 95.75 & & 0.0620 & 0.0511 \\
\hline
\end{tabular}

conduction band electrons to the adsorbed oxygen. From the above discussion, it is obvious that the synergistic effect of $\mathrm{ZnO}: \mathrm{Ag}$ and bamboo charcoal leads to the significantly enhanced photocatalytic activity. These synergistic effects of adsorptive and photocatalytic activities of the material lead to an enhancement in the degradation efficacy. Remarkably, $\mathrm{ZnO}$ :Ag/BC nanocomposite exhibits excellent photocatalytic activities for the decomposition of MB and MG under visible light irradiation.

\subsection{Antibacterial Activities}

The antibacterial activities of the prepared samples were tested against $E$. coli and $S$. aureus bacteria using the agar well method. Figure 9 shows the photographic images of the zone of inhibition for the synthesized samples, and the measured inhibition zones are summarized in Table 3. The appearance of inhibition zone obviously indicates the antibacterial activities of the synthesized samples. From Table 3, it is observed that $\mathrm{ZnO}: \mathrm{Ag} / \mathrm{BC}$ nanocomposite sample exhibits remarkably higher antibacterial activity than $\mathrm{ZnO}: \mathrm{Ag}$ sample. The possible reasons for the improved antibacterial activity of $\mathrm{ZnO}: \mathrm{Ag} / \mathrm{BC}$ nanocomposite can be elaborated as follows:

1. $\mathrm{ZnO}: \mathrm{Ag} / \mathrm{BC}$ nanocomposite may interact directly with the bacterial cell membrane by releasing zinc ions $\left(\mathrm{Zn}^{2+}\right)$.

2. $\mathrm{ZnO}: \mathrm{Ag} / \mathrm{BC}$ nanocomposite with smaller particle size and larger surface areas is more effective in generating 

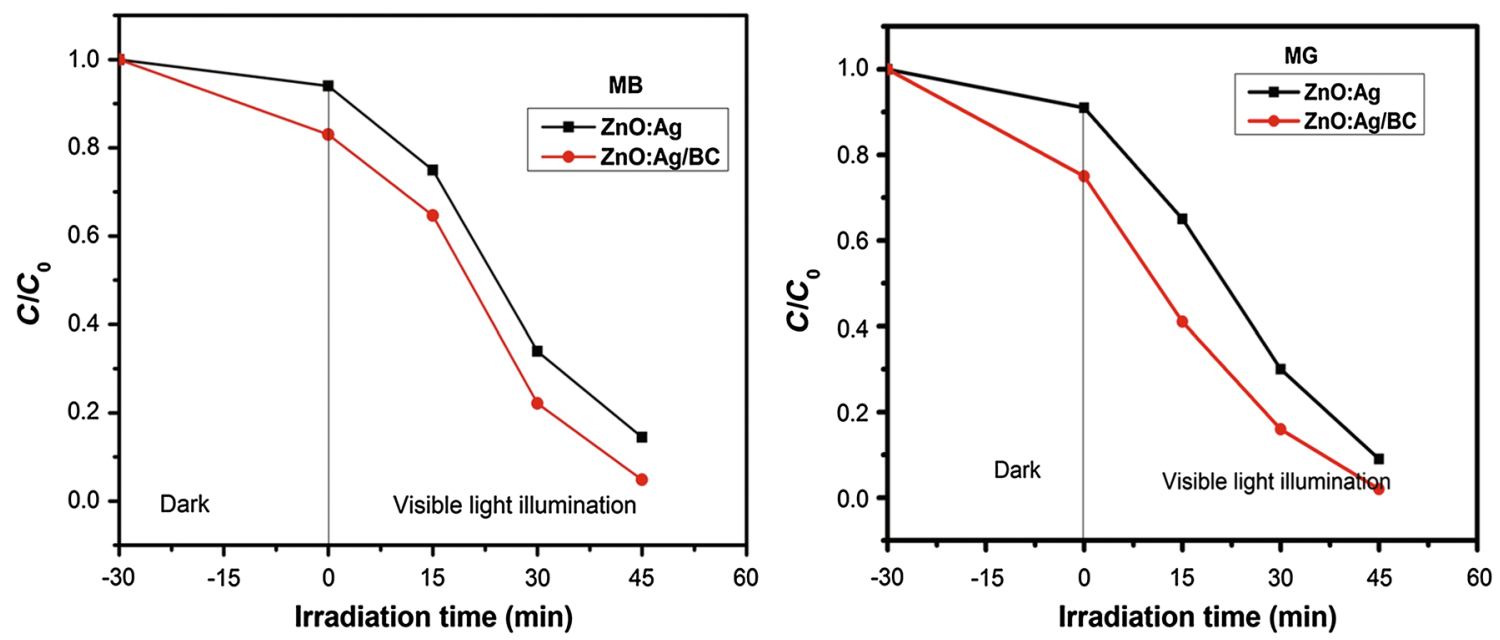

Fig. 7 Plots of $\left(C / C_{0}\right)$ versus irradiation time (MB and $\left.\mathrm{MG}\right)$ for $\mathrm{ZnO}: \mathrm{Ag}$ and $\mathrm{ZnO}: \mathrm{Ag} / \mathrm{BC}$ nanopowders
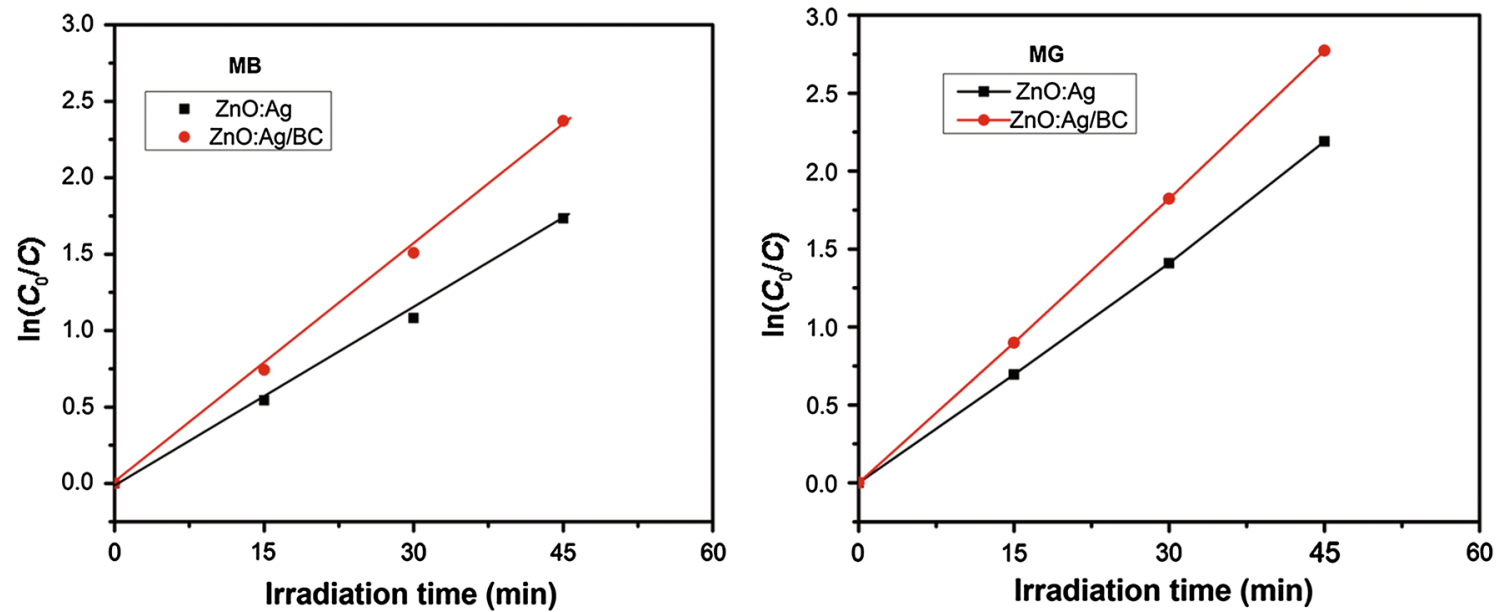

Fig. 8 Photodegradation kinetics of $\mathrm{MB}$ and $\mathrm{MG}$ using $\mathrm{ZnO}: \mathrm{Ag}$ and $\mathrm{ZnO}: \mathrm{Ag} / \mathrm{BC}$ nanopowders
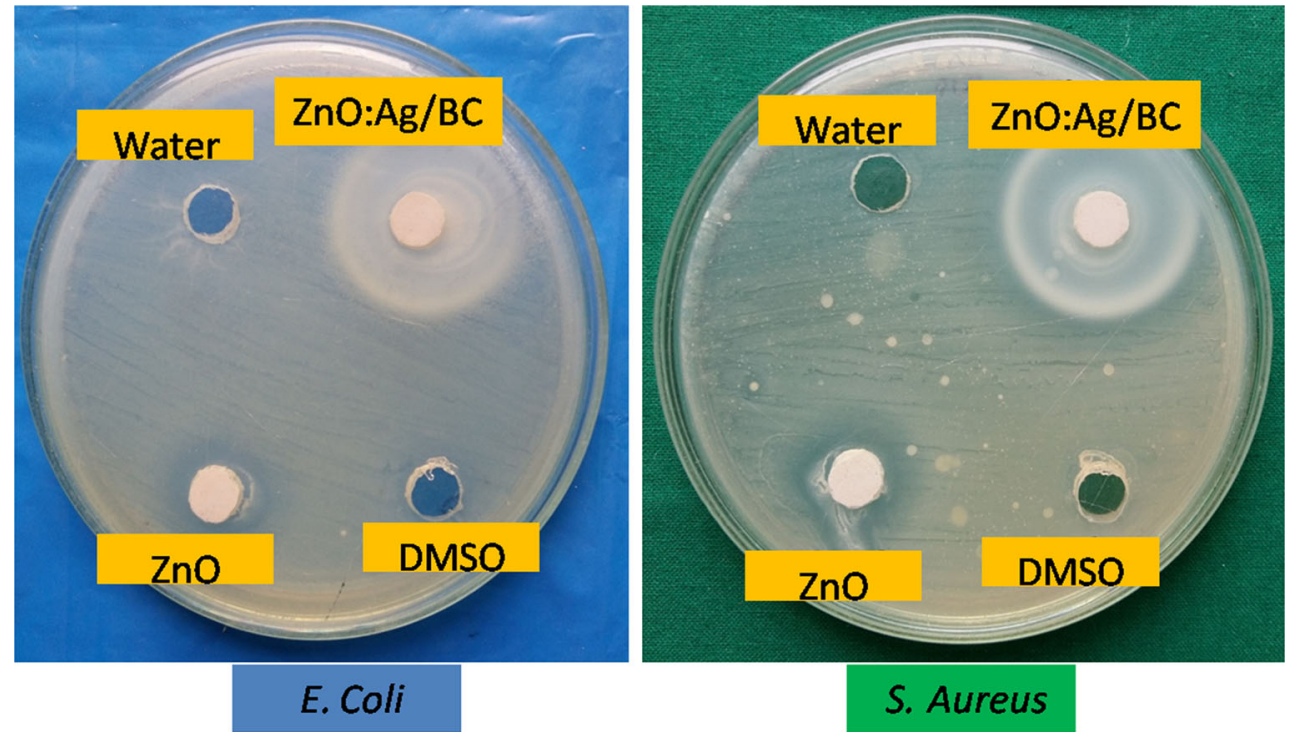

Fig. 9 Zone of inhibition caused by $\mathrm{ZnO}: \mathrm{Ag}$ and $\mathrm{ZnO}: \mathrm{Ag} / \mathrm{BC}$ nanopowders against E. Coli and S. aureus 
Table 3 Zone of inhibition observed by $\mathrm{ZnO}: \mathrm{Ag}$ and $\mathrm{ZnO}: \mathrm{Ag} / \mathrm{BC}$ nanopowders against the tested bacteria (E. coli and S. aureus)

\begin{tabular}{llll}
\hline S. no. & Bacteria & \multicolumn{2}{l}{ Zone of inhibition (diameter in $\mathrm{mm}$ ) } \\
\cline { 3 - 4 } & & $\mathrm{ZnO}: \mathrm{Ag}$ & $\mathrm{ZnO}: \mathrm{Ag} / \mathrm{BC}$ \\
\hline 1 & E. coli & 20 & 28 \\
2 & S. aureus & 21 & 30 \\
\hline
\end{tabular}

reactive oxygen species. The reactive oxygen species are capable of penetrating the cell, damage the cell membrane, spoil the cell proteins and DNA and eventually cause cell death.

3. In addition, this large surface area of the BC can lead to the adsorption of microorganism by the charcoal surfaces, improving the antibacterial activity.

\section{Conclusion}

The simple, low cost, easiness of synthesis and higher photodegradation activity of the $\mathrm{ZnO}: \mathrm{Ag} / \mathrm{BC}$ is used for wastewater treatment. $\mathrm{ZnO}: \mathrm{Ag} / \mathrm{BC}$ nanocomposite showed rapid and higher degradation of $\mathrm{MB}$ and $\mathrm{MG}$ as compared to dye removal of $\mathrm{ZnO}: \mathrm{Ag}$. The degradation rate constant of $\mathrm{MB}$ dye for $\mathrm{ZnO}: \mathrm{Ag}$ is $0.0484 \mathrm{~min}^{-1}$. It increases 1.28 times $\left(0.0620 \mathrm{~min}^{-1}\right)$ for $\mathrm{ZnO}: \mathrm{Ag} / \mathrm{BC}$ nanopowders. Similarly, in the case of MG dye the rate constant increases 1.34 times due to efficient natural adsorbent bamboo charcoal. The $\mathrm{ZnO}: \mathrm{Ag} / \mathrm{BC}$ nanocomposite proved as a promising photocatalyst toward harmful organic dyes and antibacterial agent against microorganisms.

Acknowledgements Financial support from the Department of Science and Technology-Science and Engineering Research Board (DST-SERB), India, through the research scheme (EMR/2016/ 003326) is gratefully acknowledged.

\section{References}

[1] B. Dogru Mert, B. Yaz, Acta Metall. Sin. (Engl. Lett.) 28, 858 (2015)

[2] B. Pant, M. Park, H.Y. Kim, S.J. Park, Synth. Met. 220, 533-537 (2016)

[3] G. Poungchan, B. Ksapabutr, M. Panapoy, Mater. Des. 89, 137 (2016)

[4] C.V. Reddy, J. Shim, M. Cho, J. Phys. Chem. Solids 103, 209 (2016)

[5] B. Ahmed, S. Kumar, A.K. Ojha, P. Donfack, A. Materny, Spectrochim. Acta A Mol. Biomol. Spectrosc. 175, 250 (2016)
[6] K. Santhi, C. Rani, S. Karuppuchamy, J. Alloys Compd. 662, 102 (2016)

[7] M.J. Sampaio, R.R. Bacsa, A. Benyounes, R. Axet, P. Serp, C.G. Silva, A.M.T. Silva, J.L. Faria, J. Catal. 331, 172 (2015)

[8] X.M. Hou, Mater. Lett. 139, 201 (2015)

[9] R. Meraat, A.A. Ziabari, K. Issazadeh, N. Shadan, K.M. Jalali, Acta Metall. Sin. (Engl. Lett.) 29, 601 (2016)

[10] P. Fageria, S. Gangopadhyay, S. Pande, RSC Adv. 4, 24962 (2014)

[11] N. Morales-Flores, U. Pal, E. Sánchez Mora, Appl. Catal. A-Gen. 394, 269 (2011)

[12] M. Baghdadi, E. Ghaffari, B. Aminzadeh, J. Environ. Chem. Eng. 4, 3309 (2016)

[13] P. Rajasulochana, V. Preethy, Resour. Eff. Technol. 2, 175 (2016)

[14] B. Bethi, S.H. Sonawane, G.S. Rohit, C.R. Holkar, D.V. Pinjari, B.A. Bhanvase, A.B. Pandit, Ultrason. Sonochem. 28, 150 (2016)

[15] V.K. Gupta, Suhas, J. Environ. Manage. 90, 2313 (2009)

[16] P. Liao, Z. Malik Ismael, W. Zhang, S. Yuan, M. Tong, K. Wang, J. Bao, Chem. Eng. J. 195-196, 339 (2012)

[17] L.T. Jule, F.B. Dejene, A.G. Ali, K.T. Roro, A. Hegazy, N.K. Allam, E. El Shenawy, J. Alloys Compd. 687, 920 (2016)

[18] K. Ravichandran, K. Karthika, M. Baneto, K. Shanthakumari, K.C. Lalithambika, J. Mater. Sci. Mater. Electron. 26(3), 1 (2015)

[19] M.B. Ali, F.B. Bouaifel, B. Sieber, H. Elhouichet, A. Addad, L. Boussekey, M. Férid, R. Boukherroub, Superlattices Microstruct. 91, 225 (2016)

[20] K. Ravichandran, K. Subha, N. Dineshbabu, A. Manivasaham, J. Alloys Compd. 656, 332 (2016)

[21] C. Karunakaran, V. Rajeswari, P. Gomathisankar, Solid-State Sci. 13, 923 (2011)

[22] K. Ravichandran, K. Nithiyadevi, S. Gobalakrishnan, R. Ganapathi Raman, M. Baneto, K. Swaminathan, B. Sakthivel, Mater. Technol. 31, 865 (2016)

[23] A.T. Ravichandran, K. Catherine Siriya Pushpa, K. Ravichandran, T. Arun, C. Ravidhas, B. Muralidharan, J. Mater. Sci. Mater. Electron. 27, 5825 (2016)

[24] B. She, X. Tao, T. Huang, G. Lu, Z. Zhou, C. Guo, Z. Dang, Ecotoxicol. Environ. Saf. 125, 35 (2016)

[25] D. Fu, Y. Zhang, F. Lv, P.K. Chu, J. Shang, Chem. Eng. J. s193-194, 39 (2012)

[26] X. Wang, Z. Wu, Y. Wang, W. Wang, X. Wang, Y. Bu, J. Zhao, J. Hazard. Mater. 262, 16 (2013)

[27] S.H. Lin, L.Y. Hsu, C.S. Chou, J.W. Jhang, P. Wu, J. Anal. Appl. Pyrolysis 107, 9 (2014)

[28] W. Zhang, Y. Huang, P. Liu, Y. Zhao, H. Wu, M. Guan, H. Zhang, Mater. Sci. Semicond. Process. 17, 124 (2014)

[29] E.H. Umukoro, G. Peleyeju, J.C. Ngila, O.A. Arotiba, SolidState Sci. 51, 66 (2015)

[30] K. Ravichandran, K. Nithiyadevi, B. Sakthivel, T. Arun, E. Sindhuja, G. Muruganandam, Ceram. Int. 42, 17539 (2016)

[31] T. Saidani, M. Zaabat, M.S. Aida, B. Boudine, Superlattices Microstruct. 88, 315 (2015)

[32] Y. Haldorai, A. Rengaraj, C.H. Kwak, Y.S. Huh, Y.K. Han, Synth. Met. 198, 10 (2014) 